\title{
Effects of tourism development on surface area of main lakes of Shchuchinsk-Burabay resort area, Kazakhstan
}

\author{
Makhabbat Ramazanova ${ }^{1 *}$, Mihai Bulai ${ }^{2}$, Adrian Ursu $^{3}$, Bartolomé Deyá Tortella \\ and Anuarbek Kakabayev ${ }^{5}$
}

Received: 26/03/2018 Accepted: 23/09/2018

\footnotetext{
1 University of the Balearic Islands, Spain; Sh.Ualikhanov Kokshetau State University, Kazakhstan Address: Cra. de Valldemossa, km 7.5, Code 07122, Palma, Balearic Islands, Spain. Email: m.ramazanova@uib.es

${ }^{2}$ Faculty of Geography and Geology, Alexandru Ioan Cuza University of laşi, Romania. Address: Bd. Carol I, no 20A, Code 700505, Iasi, Romania. Email: mihai.bulai@uaic.ro

${ }^{3}$ Faculty of Geography and Geology, Alexandru Ioan Cuza University of laşi, Romania. Address: Bd. Carol I, no 20A, Code 700505, lasi, Romania. Email: ursu_v_adrian@yahoo.com

${ }^{4}$ Department of Business Economics, University of the Balearic Islands, Spain. Address: Cra. de Valldemossa, km 7.5, Code 07122, Palma, Balearic islands, Spain. Email: tolo.deya@uib.es

${ }^{5}$ Faculty of Natural Sciences, Sh.Ualikhanov Kokshetau State University, Kazakhstan. Address: Abay Street, 76, Code 020000, Kokshetau, Kazakhstan. Email: anuarka@mail.ru

* Corresponding author
}

\begin{abstract}
Lake (or lacustrine) water is one of the most sensitive and vulnerable resources for many tourist destinations, whose attractiveness highly depends on the water quality and availability in the lakes. The Shchuchinsk-Burabay resort area, located in the Akmola region of the Northern Kazakhstan, is one of the most popular tourist destinations of the country, known for its attractive natural landscape and for its great number of lakes. However, during the last decades, these lakes have been facing environmental issues due to their overexploitation and increasing level of pollution. Thus, the aim of the current study is to examine the changes in surface area of these lakes during the last 30 years by using GIS technologies, and the influence of tourism industry upon this phenomenon. Accommodation facilities (hotels, sanatoriums and guesthouses), as main tourism-related water consumers, have been targeted within our analysis. Results show that tourism is one of the factors responsible for surface area decline of the main lakes in the region, and its responsibility increases when combined with other factors. This study also formulates recommendations for water management policymakers in order to guarantee the sustainability of lake water as a key resource of the tourism industry in the region.
\end{abstract}

(C) 2019 Varna University of Management. All rights reserved

Keywords: environmental issues, water resources, lake surface area, tourism, accommodation sector, Shchuchinsk -Burabay resort area, Kazakhstan.

Citation: Ramazanova, M., M. Bulai, A. Ursu, B. Tortella and A. Kakabayev (2019) Effects of tourism development on surface area of main lakes of Shchuchinsk-Burabay resort area, Kazakhstan. European Journal of Tourism Research 21, pp. 69-86

\section{Introduction}

Kazakhstan is the world's ninth largest country, located in the centre of Eurasia. It is the largest landlocked country in the world, with attractive landscapes and rich biodiversity. A special feature of its territory is that a great part of its 
surface is related to the closed drainage basins of the Caspian and Aral Seas. Thus, all inlandlake systems are facing environmental issues like overexploitation and pollution and an assessment of the water quantity changes of certain lakes has become essential.

The geographical focus of this research is the Shchuchinsk-Burabay resort area located in the Akmola region of northern Kazakhstan. Altogether, it represents one of the most popular tourist destinations in the country, with an attractive natural landscape revolving around a lake system.

The quality of the environment and most particularly of its water are key factors in attracting tourists. However, during the last years, this resort area has experienced environmental issues. During the last decades, most regional lakes have lost important amounts of water and their contamination levels have increased. High levels of evaporation, groundwater recharge and increasing human activities are the main reasons of water loss in these lakes (Yapiev et al., 2017).

The tourism infrastructure of ShchuchinskBurabay resort area is mostly concentrated on the shoreline of these lakes and has significantly developed during the last decades. Thus, its influence upon the environmental state of the lakes must be analysed. During the 2003-2017 period, the wider Akmola region experienced a significant growth in the number of accommodation establishments (an average annual growth rate of $33 \%$ ), as well as in the number of bed-places (24\%), making it the highest growth rate in the country (Committee on Statistics of the Republic of Kazakhstan, 2017).

The tourism industry is extensive, offering a diverse array of services, and generating negative direct and indirect impacts (externalities) on environmental resources. The accommodation industry is considered to be the highest water consumer subsector within the tourism industry. Growth of accommodation facilities significantly increases the levels of fresh water consumption and wastewater discharge, especially during the summer season. In addition, tourists have a tendency to consume more water resources during holidays than they do at home (Bohdanowicz \& Martinac, 2007; Gössling et al., 2012; Tortella \& Tirado, 2011).

Although the tourism industry, as well as agriculture, is considered one of the main economic activities in the region, it exerts a significant pressure on natural water resources and is responsible for the deterioration of water quality and quantity of the lakes. Nowadays, the decline in water level and changes in water quality of the main lakes of the area is one of the biggest issues in the region (Kazhydromet, 2017; Sevkaznedra, 2014; Yapiev et al., 2017). As a result, this study is crucial for the Shchuchinsk-Burabay resort area since, up to now, too little attention has been paid to assessing tourism influence on water resources in this region. This research seeks to address these gaps in the literature.

The aim of this study is to examine the changes in lake area during the last 30 years and discuss the possible influence of tourism activities upon it in the Shchuchinsk-Burabay resort area. Specifically, the objectives of this study are (1) to reveal the changes in the lake surface area during the 1987-2017 period; (2) to analyse the evolution of the tourism industry in the region during 2003-2017; (3) to discuss the variation of the lake surface and tourism growth nexus based on GIS technology outputs; (4) and consider climatic and other anthropogenic causes of the decreasing lake area in recent years. Finally, recommendations for water management policymakers will be drawn, as basis for future management plans.

\section{Literature review}

Water is one of the most critical and scarce resources for the tourism industry (UNWTO, 2013). Tourism activities require water, both in quantity and quality, for its direct and indirect consumption (Rico-Amoros et al., 2009). In recent years, the development of tourism activities has increased the levels of contamination and overexploitation of water resources (i.e., lakes, rivers, basins etc.) in several tourist destinations around the world. Furthermore, tourism growth generates water supply scarcity, which becomes the main obstacle for further tourism development. 
Pollution problems add up, both for water scarce or water abundant regions, due to unplanned consumption and management. Thus, it is essential to understand the current water consumption patterns, as future freshwater resources' availability will depend on present management and monitoring of these natural resources (Ning \& He, 2007). The organizations and authorities responsible for water management, especially those from regions with water scarcity, are starting to take into account the impact of tourism on water resources (Eurostat, 2009; UNWTO, 2013).

Nowadays tourist resort areas tend to be situated in or near the water-based attractive areas. According to Gladstone et al. (2012) coastal areas are the most attractive for tourists, thus during the last decades several concepts such as marine, coastal, river, and more recently lake tourism has been discussed in tourism literature (Hall \& Härkönen, 2006; Rodrigues et al., 2015). Often, lakes are the main attraction for many destinations: Lake Balaton for Hungary, the Great Lakes in the USA, Lombardian lakes in Northern Italy, Finnish lakeland, Lake District in the UK, etc. More than tourist attractions, lakes are crucial in supporting nearby human settlements (Cooper, 2006; Ostendorp et al., 2004) as agriculture, industry, household sector need growing freshwater resources. The growth of tourism industry has led to increasing concern about the environmental sustainability of these resources, especially when the resources are limited or already contaminated. Some authors affirm that lakes are one of the most sensitive and vulnerable providers of water for many tourist destinations which are suffering from pressure arising from tourism (Hall \& Härkönen, 2006).

Tourism activities can affect shorelines directly and indirectly, with an impact depending on the type, size and depth of the lakes. It depends as well on the type of activities undertaken in the lakes, the number of people engaged in them, the environment etc. For example, Dokulil (2014) considers that certain leisure activities such as swimming, boating and angling have a greater role. Also, airports, accommodation facilities, restaurants and certain shops produce high quantities of wastewater. The development of tourism activities, along with other human activities, has led to a growing use of fossil fuels. Over time, this has led to high levels of greenhouse gases in the atmosphere, an important cause of climate change (Dibike \& Coulibaly, 2005). Moreover, increasing water temperatures as a result of global warming favours algae blooms during peak tourist season, with negative consequences upon the lacustrine ecosystems. Consequently, both weather changes and algae blooms have a negative impact on tourism (Foghagen, 2014). All these indirect impacts lead to the pollution of lake water and cause changes in the hydrological cycle of lakes (Dokulil, 2014; Ostendorp et al., 2004). This idea has been supported by Gladstone et al. (2012), arguing that tourism has much more than simply a direct impact from tourist activities on coastal areas. There has therefore been an increasing interest in recent years in assessing the ecological state of the lakes by analysing relevant water quality parameters (Bhateria \& Jain, 2016; Kumar et al., 2014; Romanescu et al., 2016; Romanova \& Kazangapova, 2013). Some research has been conducted by analysing the links between water quality and quantity and changes of water bodies and tourism worldwide (Burak et al., 2004; Hadwen et al., 2003; Kurleto, 2013; Lange, 2015; Lin et al., 2013).

However, due to the absence of a conceptual model of possible direct and indirect impact of tourist activities on coastal areas, it is difficult to apply an existing scheme. Moreover, according to Gladstone et al. (2012), there is a profound lack of tourism statistics, especially for some recreational activities that are of great importance. Kurleto (2013) considers that the objective assessment of the influence of the tourism industry on the lake ecosystem is quite complicated even for a country like New Zealand, which is famous for its huge number of the lakes, which represent the main tourist attractions for this destination.

Additionally, several researchers pointed out that the empirical studies related to the impacts of other anthropogenic activities (land use, population increase, human direct and indirect activities) on lake water balance is limited as well (Alifujiang et al., 2017; Volchak et al., 
2017). Most of these studies are focused on single aspects, such as changes in physicochemical parameters of lake water, influence of climate change, groundwater etc. (Alifujiang et al., 2017). There have been a number of empirical studies on lake sensitivity to climatic variables. Most of them conclude that the water loss and shrinkage in lakes are induced by low precipitation and high evaporation (Angel \& Kunkel, 2010; Dibike \& Coulibaly, 2005; Mooij et al., 2005; Ostendorp et al., 2004). For example, strong water decline caused by climate change was observed in the case of Lake Constance in Europe during 1930-2002 (Ostendorp et al., 2004). Climate change is a global trend, affecting the hydrological cycle of lakes worldwide. This trend may have a long-term impact on open water bodies and significant changes are expected to occur in water availability of the lakes.

With increasing concerns on the impact of climate change on lake water and the rapid development of human society, it is becoming crucial to examine the influences of other anthropogenic factors. Recent research has shown that the main stressors determining declines in water level should be examined as a combination of climatic and anthropogenic factors (Cai et al., 2009). For example, Alifujiang et al. (2017) investigated and empirically tested the main driving forces influencing decreasing water level of the Lake Issyk-Kul in Central Asia, by using a dynamic simulation model. The model has been validated by testing historical data used for the period 1980-2012. Researchers revealed that socio-hydrologic factors had different impacts on the lake water level change, mainly water inflow dynamic (the increasing and decreasing water withdrawal from lake tributaries). Population increase, changes in land use and water demand were also important forces for the lake water level variations. Bucak et al. (2017) estimated the future levels of the Lake Beysehir in the Mediterranean region and influences of climate change and land use upon it by applying Soil and Water Assessment Tool (SWAT) model with a Support Vector Regression Model (SVR). The empirical results indicate that Mediterranean regions are in a high risk of freshwater loss caused by continuous climate changes and forecasted a $15-52 \%$ reduction in total flows by the end of the century. It is interesting to note that, according to research results, land use is not an important factor influencing the hydrological cycle of the lake. However, the development of agriculture and demand for its irrigation will exacerbate water stress. Yuan et al. (2015) also revealed that water level decline of the Dongting Lake in China might be caused by the combination of the climatic and anthropogenic factors, where rainfall is retained as main stressor during the period 1961-2002, while dam construction is more responsible for water level decline during 2003-2010. Ostendorp et al. (2004) revealed that the environmental changes of the Lake Constance in Europe were caused by climate change together with overpopulation, industry development and nonenvironmentally friendly tourism activities. According to Lake \& Bond (2007), many freshwater ecosystems in Australia have been highly affected due to the increasing water demand of agriculture, urban and/or industrial sectors. Jalili et al. (2015) argued that dramatic decline in water level of the Lake Urmia in Iran, the second largest hyper-saline lake on Earth, could have been caused by climate change or other anthropogenic effects; however, it could also be a part of natural climate variability. The results of the non-parametric trend analysis showed that the recent fall in water level of the Lake Urmia is due to anthropogenic impacts rather than natural variability. The negative influence of population density and infrastructure on lake environment has been observed in the case of Lake Constance in Europe (Ostendorp et al., 2004). Meanwhile, Hadwen et al. (2003) found out that two lakes out of fifteen are mostly degraded by tourism activities in dune lakes in Australia.

To summarise, a rapid growth of tourism development currently demands a good quality and a considerable quantity of water resources. The tourism industry generally overuses water resources for accommodation establishments. A large part of this is due to the use of water by tourists within their rooms, but also within the amenities: swimming pools and spa centres, gardens, golf courses etc. This leads to water shortages and degradation of water supplies, as well as generating a great volume of 
wastewater. The fact that fresh water availability is crucial for survival and development of all societies requires adequate consumption and management of the resources (Cooper, 2006).

A lack of research on these issues has been observed in the case of Kazakhstan. Moreover, impressive development and heavy concentration of the tourism settlements around the lakes of the case study area is considered to be responsible for shrinkage of water resources. Thus, a deeper look into the case of the Shchuchinsk-Burabay resort area in Kazakhstan becomes crucial, as it is one of the most water scarce countries on the Eurasian Continent (Ministry of Agriculture of Kazakhstan, 2017).

\section{Data and methodology}

\section{Study area and data}

The present study has applied statistical analysis by processing the official data of the Committee on Statistics of the Republic of Kazakhstan, Department of Tourism and Department of Statistics in Akmola region and Water Resources Committee of the Republic of Kazakhstan.

The official documents providing a public framework for our study are the "Law on Tourist activity in the Republic of Kazakhstan", the "Concept of development of tourism in the Republic of Kazakhstan until 2023", the Tourism Development Program in Akmola region for 2017-2019", as well as President Nazarbayev's instructions on the systematic development of the Shchuchinsk - Burabay resort area until 2020 (Department of Tourism in Akmola, 2017).

The Shchuchinsk-Burabay resort area is situated between 5250'/5310' North latitude and $70^{\circ} 00^{\prime} / 70^{\circ} 40^{\prime}$ East longitude in the Akmola region, within the Burabay district, $90-100 \mathrm{~km}$ east from Kokshetau city, the administrative centre of Akmola and $290 \mathrm{~km}$ from the capital Astana (Figure 1). The most populous towns of the district are Burabay and Shchuchinsk, with a total population of 74,921 people (Department of Statistics in Akmola, 2017). Shchuchinsk is located on the coastal zone of the Shortandy Lake and is the main transport hub between the resort area and Burabay National Nature Park. Burabay town, located on the coastal zone of the Burabay Lake, is the centre of the Shchuchinsk-Burabay resort area, focusing mainly on tourism activities. This area is a national heritage of the Republic of Kazakhstan, where natural therapeutic resources and attractive landscapes have been decisive in acquiring its status. The region has an accessible geographic location, unique natural and climatic conditions, attractive landscape with a magnificent combination of rocky mountains, pine forests, lakes and recreational areas. The climate of the resort is sharply continental with a long winter and a relatively short summer. The average daily air temperature in January is about $-17^{\circ} \mathrm{C}$, minimum temperature is $-42.5^{\circ} \mathrm{C}$. The average air temperature in July is $+20^{\circ} \mathrm{C}$, the maximum temperature is $+37.6^{\circ} \mathrm{C}$. The average amount of precipitation is $331 \mathrm{~mm} / \mathrm{year}$, and is the main supply of surface and ground water. About $70 \%$ of it falls during the warm period of the year and the region is considered arid in terms of moisture availability (Sevkaznedra, 2014). Land use mainly features flatland steppes and forested hills. The highest peak of the region is the top of Kokshetau Mountain (Sinyuha, $947 \mathrm{~m})$, situated between Ulken Shabakty and Burabay Lakes. The mountain range of Kokshetau stretches for more than $30 \mathrm{~km}$ from north to south. The slopes of the mountains are covered with pine and pine-birch forests which dominate the natural appearance of the area and create a favourable microclimate.

The lakes of the Shchuchinsk-Burabay resort area are of immense cultural, recreational and environmental value. Acknowledgement of these values have significantly contributed to the successful nomination of the lakes of the Northern Kazakhstan as a UNESCO World Heritage Site in 2008.

Surface water sources of the area are represented by a series of large and deep lakes, which have been formed by tectonic movement. They are fed by atmospheric precipitation, underground sources, and partly by small rivers and temporary streams. The water level constantly fluctuates, as in summer time some small lakes might dry up and turn into dry "sores" with rare vegetation. Four main 
lakes of the Shchuchinsk-Burabay resort area (Burabay, Shortandy, Ulken Shabakty and Kishi Shabakty Lakes) are examined in this study. Some characteristics are described below (Table 1).

\section{GIS methodology}

Open-source QGIS software has been used to perform spatial and temporal analysis. In order to assess the anthropogenic impact on natural water resources, satellite images provided by Landsat Earth coverage program and Sentinel mission have been used together with remote sensing techniques. Based on the resolution and cloud cover, six Landsat images for 19872012 (Landsat 4 is for 1987, 1991, 1996,
Landsat 7 is for 2000, 2007, 2012) and one Sentinel 2 image for 2017 have been selected for spatial-temporal analysis of the case-study area. Seasonal fluctuations of the lacustrine levels reflect the annual hydrologic cycle, which is characterized by higher water levels during the spring and summer (about $70 \%$ of precipitation fall during this period of the year). Thus, images of the period 1 May - 31 August of the years 1987-2017 have been used, as they were characterized by higher water levels. The spatial data has been re-projected in WGS84 cartographic system - Universal Transverse Mercator (UTM) projection fuse 42N (EPSG:3857), specific for Kazakhstan.

Table 1. Morphological characteristics of the lakes

\begin{tabular}{llllll}
\hline Lakes & $\begin{array}{l}\text { Length } \\
(\mathbf{k m})\end{array}$ & $\begin{array}{l}\text { Width } \\
\mathbf{( k m})\end{array}$ & $\begin{array}{l}\text { Depth } \\
(\mathbf{m})\end{array}$ & $\begin{array}{l}\text { Max.depth } \\
(\mathbf{m})\end{array}$ & $\begin{array}{l}\text { Water catchment } \\
\text { area }\left(\mathbf{k m}^{2}\right)\end{array}$ \\
\hline Burabay & 4.6 & 3.2 & 2.8 & 7.0 & 164.0 \\
Shortandy & 7.2 & 3.7 & 8.2 & 19.0 & 69.4 \\
Ulken Shabakty & 8.3 & 5.1 & 8.2 & 33.0 & 150.0 \\
Kishi Shabakty & 8.3 & 2.6 & 4.2 & 15.0 & 139.0 \\
\hline
\end{tabular}

Source: Sevkaznedra, 2014.

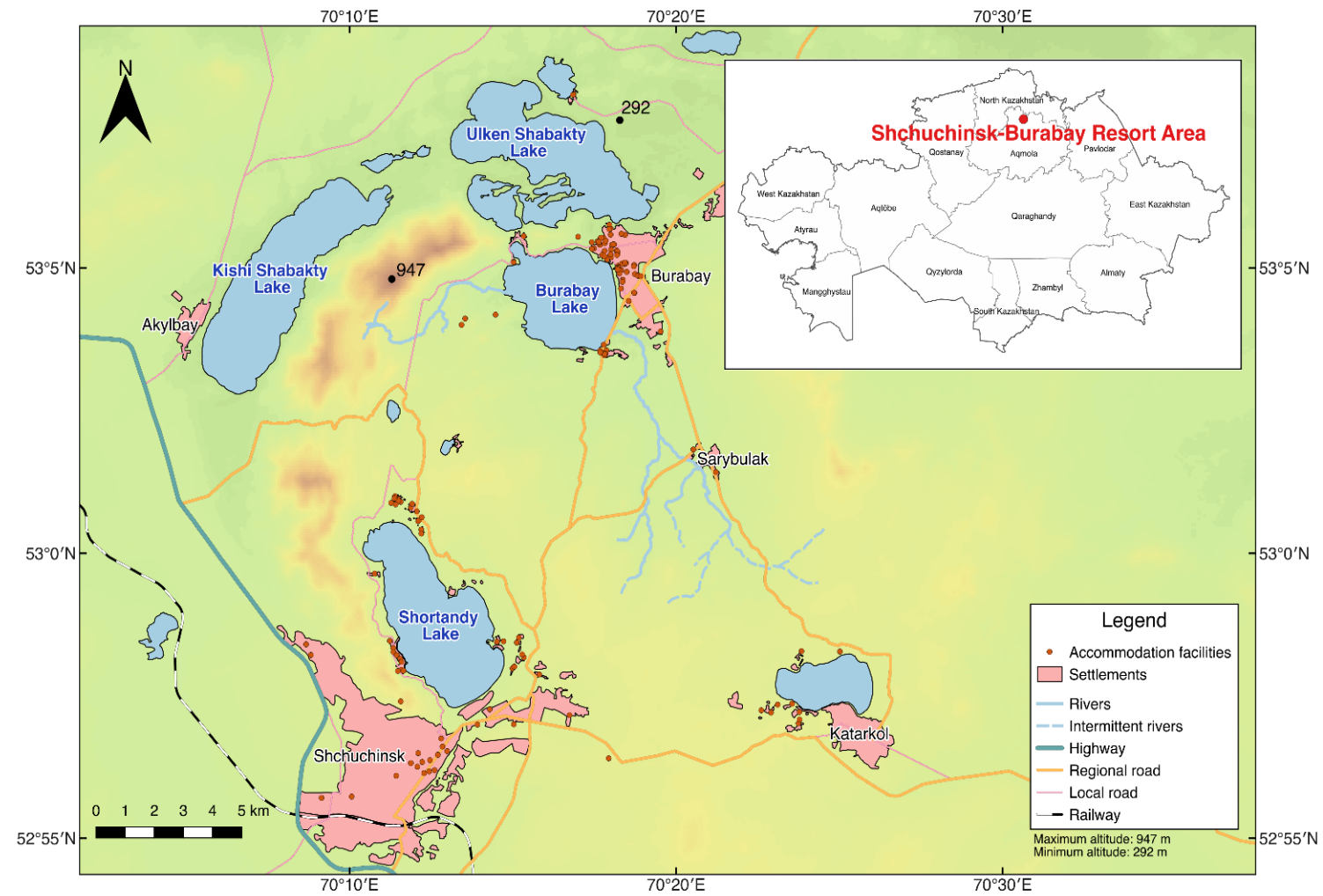

Figure 1. Study area map 
Table 2. Dynamics of changes in the lake surface area from 1987 to 2017

\begin{tabular}{ccccc}
\hline & $\begin{array}{c}\text { Burabay Lake } \\
\text { Area (sq. km) }\end{array}$ & $\begin{array}{c}\text { Shortandy } \\
\text { Lake } \\
\text { Area (sq. km) }\end{array}$ & $\begin{array}{c}\text { Ulken Shabakty } \\
\text { Lake } \\
\text { Area (sq. km) }\end{array}$ & $\begin{array}{c}\text { Kishi Shabakty } \\
\text { Lake } \\
\text { Area (sq. km) }\end{array}$ \\
\hline $\mathbf{1 9 8 7}$ & 10.0167 & 16.7191 & 21.3141 & 18.0857 \\
$\mathbf{1 9 9 1}$ & 9.9916 & 16.1855 & 20.8552 & 17.9243 \\
$\mathbf{1 9 9 6}$ & 9.8912 & 15.8223 & 20.6295 & 18.0173 \\
$\mathbf{2 0 0 0}$ & 9.9524 & 15.4889 & 19.9421 & 17.5115 \\
$\mathbf{2 0 0 7}$ & 9.9123 & 14.7984 & 19.6523 & 17.5101 \\
$\mathbf{2 0 1 2}$ & 9.9451 & 14.9688 & 18.7656 & 16.8902 \\
$\mathbf{2 0 1 7}$ & 9.9427 & 14.8686 & 18.2053 & 16.8843 \\
$\begin{array}{c}\text { Total decline (\%) } \\
\text { Average annual } \\
\text { decline (\%) }\end{array}$ & $-1 \%$ & $-11 \%$ & $-15 \%$ & $-7 \%$ \\
\hline
\end{tabular}

Source: QGIS outputs.

The purpose of using GIS software in the present study is to perform a mapping of the case study area, by taking into account main water resources, human settlements and tourism components, such as accommodation facilities.

GIS provided a tool in order to observe lake area changes over a long timescale (19872017). Due to the absence of data from official sources on tourism evolution indicators for the last 30 years, GIS has been applied as well. For this the accommodation sector has been targeted, as it is a possible driver responsible for lake surface decline in the studied region.

By using the ability of GIS to locate geographical objects across time and space, we distributed tourism accommodation establishments around each lake for the years 1987, 1991, 1996, 2000, 2007, 2012 and 2017, based on the year of construction of the establishments. Mapping enabled to spot the changes in a number of tourism accommodations in the past 30 years, as well as the changes in the surface area of the lakes.

\section{Results and analysis}

Surface area changes in the studied lakes

The changes of lake surface area focused on the results of the GIS interpretation over the 30-year period (1987-2017) from a temporal and geospatial perspective presented in the Table 2.
As presented in the table, over the 30-year period, the lakes of the region experienced visible declines in the water surface. The causes are decreased level of precipitation, increased temperature of the surface water area resulting in high levels of evaporation, growth of population and industry, uncontrolled withdrawal of water from the lakes, agricultural run-off and increase of livestock farming (Sevkaznedra, 2014). According to Sevkaznedra (2014), of the 10-12 million $\mathrm{m}^{3}$ water deficit in 2013 , around $65-70 \%$ was due to anthropogenic factors.

Moreover, small rivers of the examined resort area are short and shallow, their valleys are poorly expressed, and in recent years groundwater participates less in feeding them. Their level and consumption depend on weather and climate conditions. The main surface run-off occurs during the period of spring snowmelt. As temperatures increase, the rivers dry out in the summer. Changes in precipitation, run-off to the water catchment basin, directly affect the water level and area of the lakes.

The research conducted by Yapiyev et al. (2017) on the main hydrological processes and current state of water resources in Burabay National Nature Park indicates the increasing concern on the tendency of lakes to dry up, which is caused by various factors. According to their research, the decline in water levels of the lakes could be explained by steadily increasing air temperature and level of 
Effects of tourism development on surface area of main lakes of Shchuchinsk-Burabay resort area, Kazakhstan.

Table 3. Indicators of tourism development in Akmola region and Burabay, 2006-2015

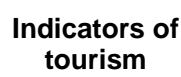

tourism

development/

2006

20072008

2009

2010

2011

2012

2013

2014

2015

Annual

average

growth

Number of establishments, units

\begin{tabular}{|c|c|c|c|c|c|c|c|c|c|c|}
\hline Akmola region & 66 & 84 & 97 & 123 & 225 & 231 & 165 & 228 & 292 & 319 \\
\hline Burabay & 28 & 31 & 36 & 40 & 125 & 156 & 141 & 140 & 187 & 203 \\
\hline$\%$ for Burabay & $42 \%$ & $37 \%$ & $37 \%$ & $33 \%$ & $56 \%$ & $68 \%$ & $85 \%$ & $61 \%$ & $64 \%$ & $64 \%$ \\
\hline
\end{tabular}

\section{Number of rooms, units}

\begin{tabular}{|c|c|c|c|c|c|c|c|c|c|c|c|}
\hline Akmola region & 1200 & 1601 & 1880 & 1974 & 2475 & 2696 & 2886 & 3682 & 4539 & 4838 & $17 \%$ \\
\hline Burabay & 201 & 403 & 529 & 907 & 1230 & 1453 & 1639 & 2256 & 3008 & 3173 & $38 \%$ \\
\hline$\%$ for Burabay & $17 \%$ & $25 \%$ & $28 \%$ & $46 \%$ & $50 \%$ & $54 \%$ & $57 \%$ & $61 \%$ & $66 \%$ & $66 \%$ & \\
\hline \multicolumn{12}{|c|}{ Number of beds, units } \\
\hline Akmola region & 2444 & 3245 & 3787 & 3990 & 5893 & 5827 & 6287 & 9572 & 11922 & 12703 & $21 \%$ \\
\hline Burabay & 367 & 769 & 1030 & 1925 & 3310 & 3211 & 3608 & 6045 & 8233 & 8704 & $47 \%$ \\
\hline$\%$ for Burabay & $15 \%$ & $24 \%$ & $27 \%$ & $48 \%$ & $56 \%$ & $55 \%$ & $57 \%$ & $63 \%$ & $69 \%$ & $69 \%$ & \\
\hline
\end{tabular}

Source: Department of Statistics in Akmola, 2017.

evaporation, decreasing level of snowmelt inflow, and high anthropogenic consumption of groundwater resources. Researchers have investigated the changes in water level in three out of the four lakes in our case-study Shortandy, Ulken Shabakty and Burabay for the period 2008-2015. They observed a steady decline in water level, averaging of $15-20 \mathrm{~cm}$ per year. The research conducted by "National Laboratory of Astana" (2016) emphasizes this concern. According to their forecasting for the period 2007-2093, obtained based on Regional climatic modelling PRECIS, the precipitation in the region will slightly increase, while the air temperature will increase rapidly. This will lead to an increase in the deficit of air humidity, to a higher evaporation at the surface of lakes, and a higher aridity in the area. Due to the increase in temperature, the risk of lakes drying out will increase and may even lead to a catastrophic disappearance of the lakes. Thus, the current situation is at high risk and requires urgent measures to preserve water resources.

In the case of the Shchuchinsk - Burabay resort area in Kazakhstan, research has been conducted on the geological state, hydrological cycle of water resources, the influence of climate change, weather forecasting, hydrology of large lakes. The recent research on the main hydrological processes and current state of water resources in Burabay National Nature Park has been developed by Yapiyev et al. (2017), whereas research of tourism impact has been neglected. A closer look could help identify future risks and make a contribution to the process of designing policies and laws regarding preserving water resources.

Tourism development in the ShchuchinskBurabay resort area

The environment of the Burabay area is suitable for various types of tourism such as medical and health, ecological, educational, cultural, adventure and sport. Mountainous landscape, pine forests, clean air, mountain lakes, rich hydro-mineral resources, iodinebromine mineral water in the surrounding areas are important curative factors that attract tourists to the area (Pyatov, 2007). This has led to comparing the region with European balneological and mountain climate resorts found in Italy, Austria, Germany, Switzerland, France and Romania. Thanks to these conditions, the Burabay region has been selected as a priority region for tourism development and the Government of Kazakhstan has developed various strategies 
and programs (Department of Tourism in Akmola, 2017). Some figures illustrate the active growth of the tourism industry (Table 3 ). For example, for the period 2003-2017, the number of accommodation establishments, rooms and beds in Akmola region has the highest growth in Kazakhstan. From only 6 establishments in 2003, the region went up to 338 establishments in 2017, with an annual average growth of $33 \%$, considering that the Shchuchinsk-Burabay resort area accounts for around $65 \%$ of all tourism infrastructure in Akmola. During the summer period, the population of the area increases up to five times, while during weekends it may go up to 10 times. Budnikova et al. (2010) reported that the number of tourists in the area was around 500000 per year during 2006-2010. The number of tourists using accommodation establishments has increased as well, with an average annual growth rate of $15 \%$ in Akmola and $38 \%$ in the Shchuchinsk-Burabay resort area for the period 2003-2017. Most tourists come from Kazakhstan and neighbouring regions of Russia, followed by EU, USA and China.

These figures show a significant growth of the tourism industry during the last ten years. It has a great economic importance as it provides good employment opportunities and other benefits to the investors and the local community. However, at the same time, tourism development generates considerable environmental imbalance as a result of its activities. Although it is a main driver of regional economic development, the tourism industry creates a demand for natural resources, especially for water.

\section{The lake area and the tourism growth nexus}

The United Nations Environmental Programme stated that water level decline in lakes is caused by overuse of resources. It is necessary to observe historical variability of lake areas. In the case of our case study area, we observed that over the 30-year period, the lakes of the region experienced visible declines in the surface area. Despite slight declines in the lake surface area from 1987, the examined lakes have been affected by the tourism industry only in recent years. Moreover, according to the Sevkaznedra (2014), over the past 47 years the hydrogeological and geoecological conditions of the area have not significantly changed. Thus, the area might be only negatively influenced by rising human activities, agriculture and regulation of surface runoff during recent decades. However, to date the reasons of lake area decline have not been fully understood. Thus, we attempt to understand the possible influence of tourism industry on lake area during the last decades, with the period of 2000-2002 considered as a turning point in tourism growth in the region.

When examining the behaviour of each lake, an important surface reduction is revealed for Ulken Shabakty Lake (15\%). This area needs a lot of attention, especially as the process is ongoing and tourism continues to increase. The high concentration of accommodation establishments on the shoreline of Burabay Lake affects the water volume and area of Ulken Shabakty Lake, as both lakes are connected through an outflow river from Burabay.

The surface area for Burabay Lake itself has only declined by $1 \%$ during the last 30 years with an average annual decline of $0.02 \%$, a relatively small number when compared to the other lakes. However, the biggest number of accommodation facilities are concentrated here. The main natural factor affecting the lake level is the amount of inflow. Burabay lake is fed from four rivers (Sarybulak, Imanbulak and two unnamed), in comparison with the other lakes which do not have this generous inflow. This explains why Burabay has maintained the same level of water surface area during a longer period of time. In addition, the establishment of Burabay National Natural Park on the coastal area of this lake, in the year 2000 , could be another factor of water level stability. Over the time, the planning and development measures over Burabay Lake could have been more cautious and focused on sustainability. 
Surface area of Shortandy Lake has declined nearly $11 \%$ during the last 30 years. The drop of nearly $1 \mathrm{sq}$. $\mathrm{km}$ every 10 years is partially due to tourism development, but only as an adding factor to the presence of the nearby city of Shchuchinsk (46 024 inhabitants in 2017), the greatest in the area and highly dependent on water consumption.
It is interesting to note that Kishi Shabakty Lake is not surrounded by tourism accommodation businesses. It seems that there is little or no direct influence of the tourism industry on the environmental state of the lake. Lack of easy access by road diminishes the effects of tourism. However, as the beaches of the other lakes tend to be overcrowded and with poor water quality during high tourist season,
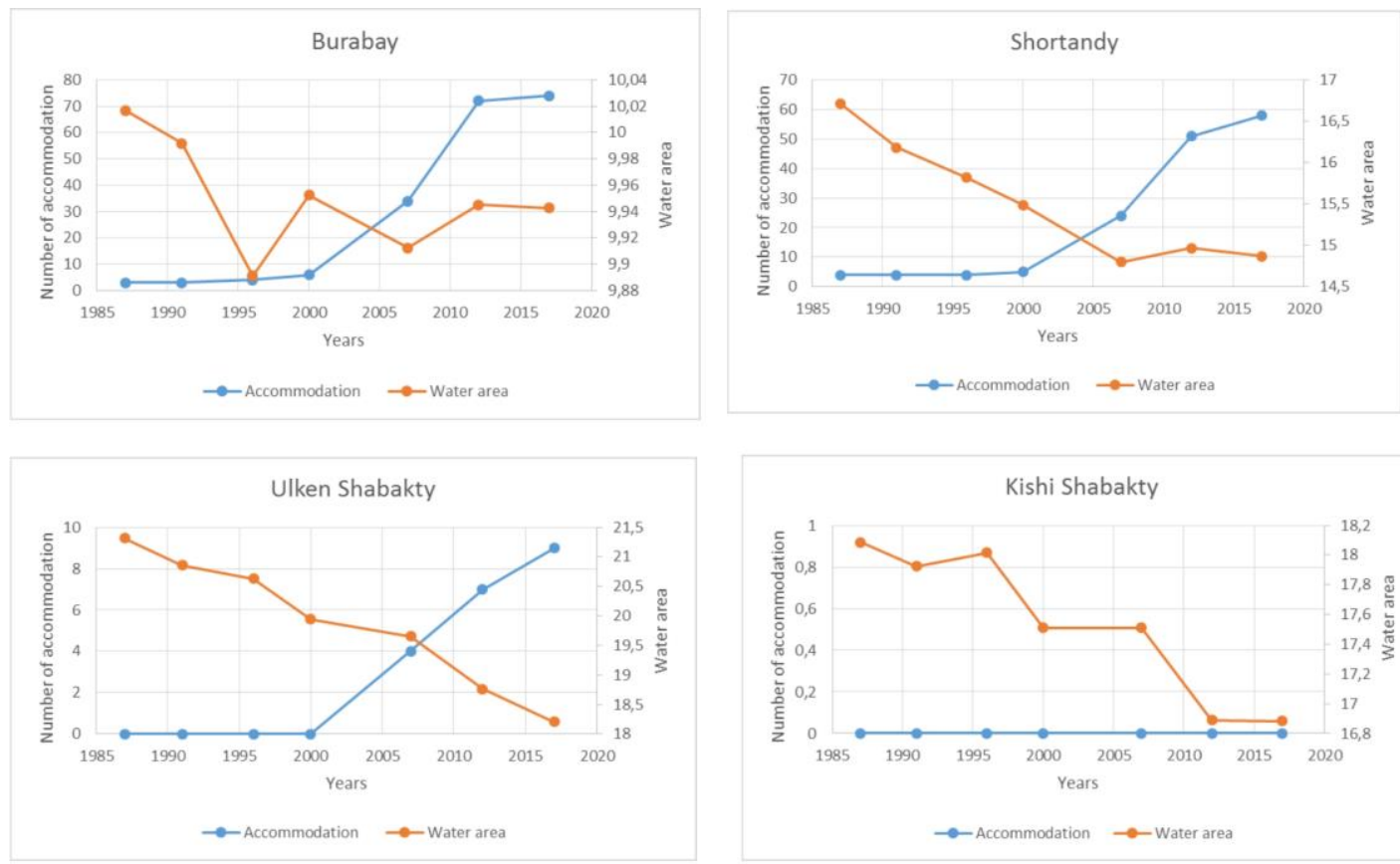

Figure 2. Number of accommodations and water area of lakes for the period 1987-2017

Table 4. Distribution of accommodation facilities around the lakes (1987-2017)

\begin{tabular}{lcclcc}
\hline Lakes & Years & $\begin{array}{l}\text { Number of } \\
\text { accommodation } \\
\text { facilities }\end{array}$ & Lakes & Years & $\begin{array}{l}\text { Number of } \\
\text { accommodation } \\
\text { facilities }\end{array}$ \\
\hline \multirow{5}{*}{ Burabay } & 1987 & 3 & & 1987 & 0 \\
& 1991 & 3 & Ulken & 1991 & 0 \\
& 1996 & 4 & 1996 & 0 \\
& 2000 & 6 & Shabakty & 2000 & 0 \\
& 2007 & 34 & 2007 & 4 \\
& 2012 & 72 & & 2012 & 7 \\
\hline \multirow{5}{*}{ Shortandy } & 2017 & $74(3342$ beds) & & 2017 & 9 (390 beds) \\
& 1987 & 4 & & 1987 & 0 \\
& 1991 & 4 & & 1991 & 0 \\
& 1996 & 4 & Kishi & 1996 & 0 \\
& 2000 & 5 & Shabakty & 2000 & 0 \\
& 2007 & 24 & & 2007 & 0 \\
& 2012 & 51 & & 2012 & 0 \\
\hline
\end{tabular}


tourists tend, more and more, to visit the unspoiled beaches of Kishi Shabakty Lake. Thus, the absence of tourism infrastructure, does not necessarily mean that there is no environmental impact of this industry.

\section{Water consumption by accommodation sector}

Accommodation establishments are considered the most important components of tourism with high water consumption. Development of accommodation facilities increased the levels of fresh water consumption and wastewater discharge, especially during peak tourist season. In addition, tourists consume more water resources when on holiday than they would usually do at home (Bohdanowicz \& Martinac, 2007; Charara et al., 2011; Essex et al., 2004; Gössling et al., 2012; Kasim et al., 2014; Tortella \& Tirado, 2011). The high intensity of water consumption by the accommodation sector usually leads to overexploitation, water scarcity, water supply degradation and generation of big volumes of sewage water (Sulnu, 2003). This problem is exacerbated if we take into account that the most popular tourism destinations are usually located in regions with water scarcity problems, like for example many coastal and island tourist destinations (Tortella \& Tirado, 2011).

For the Shchuchinsk-Burabay resort area, the years 2000-2002 were a turning point in the increase of accommodation businesses. Since then, the number of hotels has grown by $11.5 \%$ per year in the area. Figure 2 clearly shows that a growing number of tourism facilities corresponds to a decreasing surface area of the lakes.

Most tourism establishments (74) are located in the coastal area of Burabay Lake, 58 are around Shortandy Lake, and nine are concentrated close to Ulken Shabakty Lake. However, it is interesting to note that the indicator "number of beds" presents different results for the year 2017 (Table 4). The majority of the accommodation establishments in terms of the numbers of beds is located on the shoreline of Shortandy Lake (4497 bed places), while the accommodation facilities with fewer beds are located close to Burabay Lake (3342 bed places). This is explained by the fact that most public sanatoriums (with great number of the beds) are located on the coastal area of Shortandy Lake. The construction of the first health centres and sanatoriums began in the early $20^{\text {th }}$ century on the coastal area of the Burabay and Shortandy lakes, and development continued in the middle of the $20^{\text {th }}$ century, aimed at using local mud and mineral waters for treatment. These establishments have become popular as excellent resorts for treatment and wellness. However, by analysing the sanatoriums as accommodation type in terms of water consumption, it is noticeable that sanatoriums are the highest accommo-

Table 5. Average water consumption in accommodation types (2014-2015)

\begin{tabular}{lccc} 
& Hotels & Sanatoriums & Guesthouses \\
\cline { 2 - 4 } $\begin{array}{l}\text { Average water consumption per } \\
\text { guest per night (L) in 2014 }\end{array}$ & 194.75 & 436.22 & 172.58 \\
$\begin{array}{l}\text { Average water consumption per } \\
\text { guest per night (L) in 2015 }\end{array}$ & 236.03 & 439.00 & 181.90 \\
\hline
\end{tabular}

Source: Ramazanova et al., 2016.

Table 6. Total water consumption in accommodation types (2015)

\begin{tabular}{llllll}
\hline $\begin{array}{l}\text { Accommodation } \\
\text { types }\end{array}$ & $\begin{array}{l}\text { Number of } \\
\text { accommodation } \\
\text { type (units) }\end{array}$ & $\begin{array}{l}\text { Average } \\
\text { number of } \\
\text { beds (units) }\end{array}$ & $\begin{array}{l}\text { Average } \\
\text { water } \\
\text { consumption } \\
\text { per guest per } \\
\text { night (litres) }\end{array}$ & $\begin{array}{l}\text { Average } \\
\text { occupation } \\
\text { level per year } \\
\text { (\%) }\end{array}$ & $\begin{array}{l}\text { Water } \\
\text { consumption } \\
\text { per year }\left(\mathbf{m}^{3}\right)\end{array}$ \\
\hline Sanatoriums & 24 & 323 & 439.00 & $75(274$ days) & 932457 \\
Hotels & 73 & 62 & 236.03 & $60(219$ days) & 233952 \\
Guesthouses & 54 & 26 & 181.90 & 55 (201 days) & 51333 \\
Total water consumption per year & & & & 1217742 \\
\hline
\end{tabular}

Source: Ramazanova et al.. 2016. 
dation water consumers. According to research work of Ramazanova et al. (2016) water consumption in sanatoriums of the Shchuchinsk - Burabay resort area account for 436-439 litres per guest per night, while hotels consume $194.75-236.03 \mathrm{~L} / \mathrm{G} / \mathrm{N}$, and guesthouses 172.58-181.90 L/G/N. (Table 5). High water consumption in the sanatoriums is caused by a wider range of medical and therapeutic services and activities, many of which are based on the consumption of water resources (hot water, cold water, mineral water, healing water, freshwater). Hamele \& Eckardt (2006) highlighted that different types of accommodation consume different amounts of water. It also has been found by Hadjikakou et al. (2013) that the type of accommodation is one of the main factors impacting water consumption. For example, budget accommodations have a much lower environmental footprint, when compared to the luxurious ones. Gössling (2001) also found that daily water consumption per tourist in hotels of Zanzibar is much higher than in guesthouses.

Tourism water consumption has not been well documented in statistics. This lack is also found in many other tourist destinations worldwide (Eurostat, 2009; Gössling et al., 2012), as tourism-related water consumption statistics are usually combined with 'urban' water consumption statistics (Tortella \& Tirado, 2011). Thus, our study attempts to calculate the total water consumption per year, for each of the three types of accommodation. The calculations are based on our previous research methods for determining a water consumption indicator (water use per guest per night) in order to understand the main factors that influence water consumption in the facilities of the Shchuchinsk-Burabay resort area.

Results show an average water consumption of $38852 \mathrm{~m}^{3}$ per year in one sanatorium, 3205 $\mathrm{m}^{3} /$ year in hotel, and $951 \mathrm{~m}^{3} /$ year in guesthouse. Total water consumption per year has been $1217742 \mathrm{~m}^{3}$ (Table 6). The results are similar to those of obtained by Sevkazndera's team in the summer of 2014. They calculated the water extraction from the wells of the sanatoriums and revealed that the amount of water extraction per day is averagely $100-120 m^{3}$ (36 $500-43800 m^{3}$ annually).

Tourism growth and seasonality, combined with agricultural planting and industrial activities, lead to water supply shortages in the region, which cause imbalances between water demand and water supply. Table 7 indicates that during the last 5 years, there has not been observed a considerable change in the size of the local population. However, there is a growth in the number of tourists and accommodation establishments in the region, leading to higher total water consumption. The situation is exacerbated by the fact that most hotels and other accommodation types in the area are not supplied by the central water system and still use pumping wells.

The overview of water consumption patterns within the accommodation establishments indicates the negative effects of tourism on water availability in lakes. However, the total water consumption of the accommodation

Table 7. Number of tourists and local people in Burabay

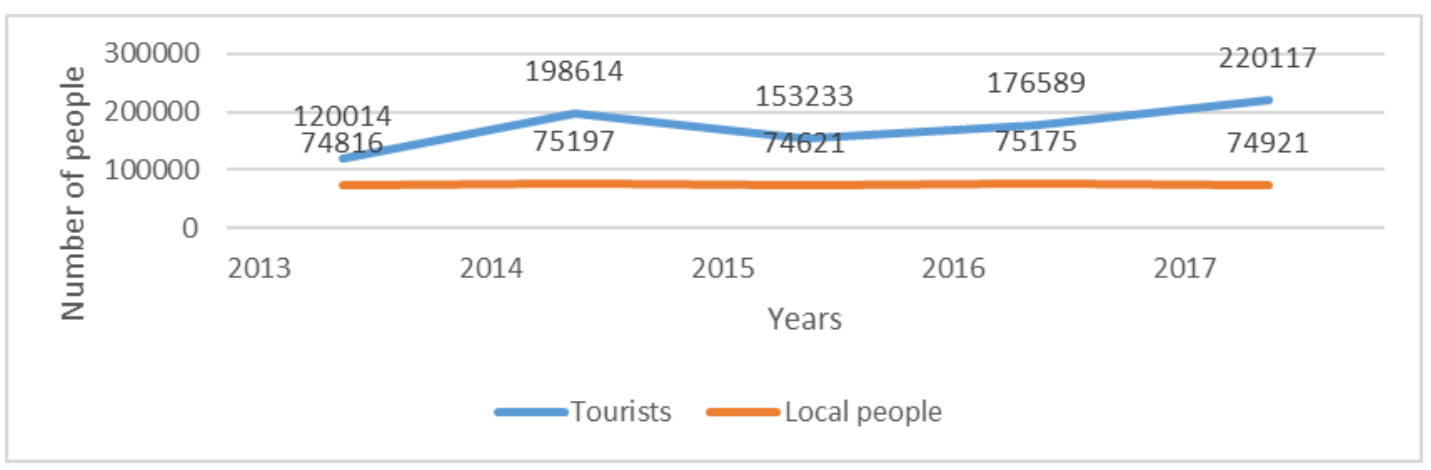


industry is more complex, if we take into account all the water required to maintain the tourism industry. Thus, recent research outlined three dimensions of water use, such as direct, indirect and systematic water use. Tourism infrastructure requires substantial amounts of water resources to be operational (Gössling et al., 2015). Moreover, the tourism industry during high season could compete with other industries in the region. In this sense, Eurostat (2009) noted that, in some Mediterranean countries, conflicts exist between hydroelectricity production, agriculture and tourism industry during summer, and the priority is sometimes given to the accommodations. Thus, the potential influence of the tourism industry on water availability should be taken into consideration, keeping in mind the suggestion of the UN Water Report (2015), that global water demand will increase by $55 \%$ by 2050 due to the growing demand of various industries and domestic uses (Connor, 2015).

\section{Other factors}

Various factors contribute to the conditions the lakes are experiencing today. Lately, one may notice a relatively stable level of long-term annual precipitation and increasing level of water evaporation due to the rising temperature. Other factors such as land use, agriculture, irrigation, industry, infrastructure and local population could influence the water area of the lakes. Shchuchinsk town, Burabay and Akulbay villages (with a total population of 74921 in 2017) are located on the shore of the lakes. Furthermore, lake water has long been the main supply source for Shchuchinsk town. As there are many residents living without sewage treatment or with sewage systems in poor conditions, there is a growing contamination of both ground and surface water resources. Shchuchinsk experienced an important population growth until 1991, but then a drop of $17 \%$ in the following 25 years, although accompanied by infrastructural development, extensive resource-consuming activities. The presence and operation of industry nearby result in additional pressure on natural water resources.

According to the Water Resources Committee of the Republic of Kazakhstan (2016), average water consumption per person per day in Kazakhstan is 82 litres, three times less than the average water consumption by tourists in Shchuchinsk-Burabay resort area, which is in line with the previous literature findings. Water extraction from the wells in Burabay town is $900 \mathrm{~m}^{3}$ per day, leading to a total water consumption per year $328500 \mathrm{~m}^{3}$. Akulbay town, located on the shoreline of Kishi Shabakty Lake, extracts $50 \mathrm{~m}^{3}$ of water from the wells per day, which accounts for 18250 $\mathrm{m}^{3}$ per year (Sevkazndera, 2014). Shchuchinsk town, which is mostly provided by a central water system, accounts for 45441 inhabitants (2015 year), where water consumption per person per day is 82 litres (Water Resources Committee, 2016). Thus, total water consumption by Shchuchinsk population is 1360050 $\mathrm{m}^{3}$ per year.

The above-mentioned data clarifies that in the Burabay region, the accommodation sector combined with the household sector is an important consumer of water resources (2 924 $542 \mathrm{~m}^{3}$ per year). Its share of the water volume of the examined lakes $\left(381.5 \mathrm{mln} \mathrm{m}^{3}\right)$ is approximately $0.8 \%$ per year. This is exacerbated by the fact that tourism accommodation infrastructure is overloaded in the water catchment basin of Burabay Lake and its ongoing growth character highlights the risks of increasing water extraction and wastewater discharges into the lake. Furthermore, accommodation facilities are planned to increase along the Lakes Ulken Shabakty and Kishi Shabakty (Department of Tourism in Akmola, 2017).

The annual volume of extracted groundwater to supply anthropogenic needs (including tourism sector) cannot be renewed, as sewage water is discharged far away from the water catchment basin of the area, due to non-existent wastewater treatment plants. This situation leads to a negative water balance of the lakes' environment. It should be noted that these processes are irreversible and the environmental issues concerning the lakes must be addressed in early stages (Cooper, 2006). 
According to the results of Sevkazndera (2014), overexploitation of groundwater is already considerable in the area. It provokes not only water deficit, but also saline water intrusion, that in turn has negative impacts on the quality of freshwater. Kazhydromet (2017) reported that the water quality of the lakes is already low in the region. Moreover, historical data shows that relatively stable levels of long-
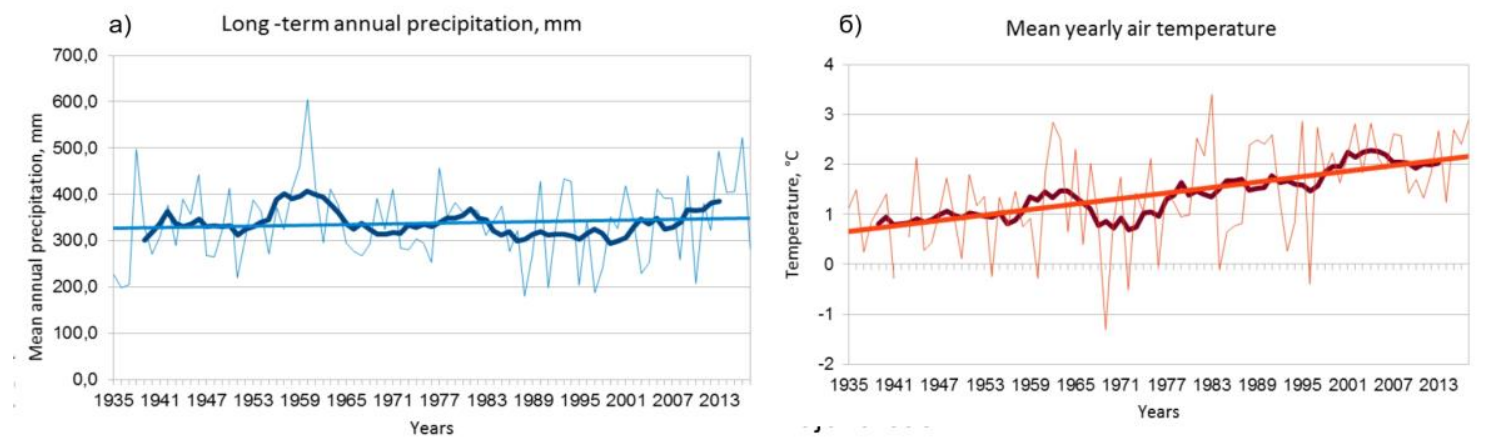

Figure 3. Annual precipitation and mean air temperature

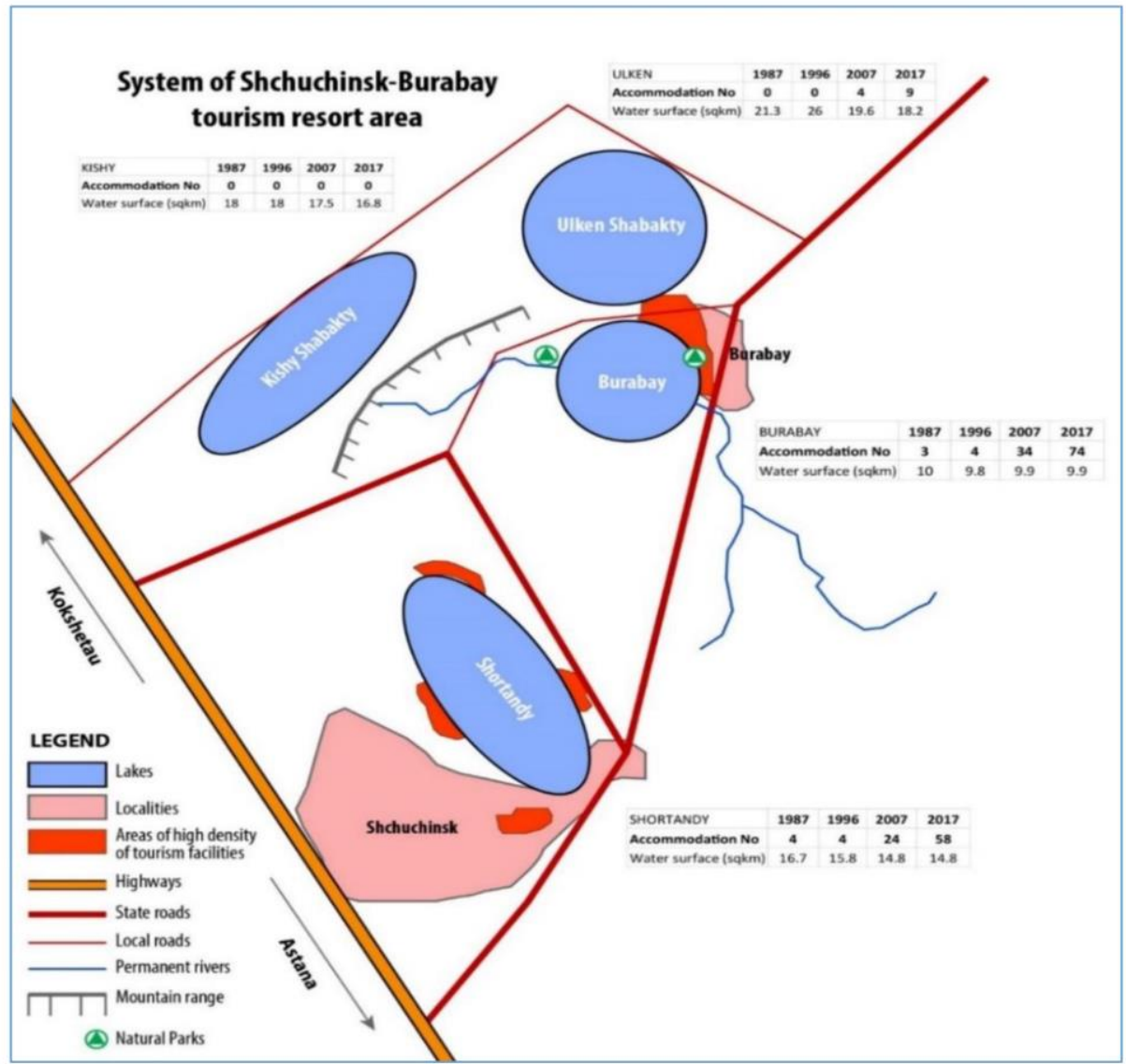

Figure 4. Schematic situation of Shchuchinsk-Burabay resort area 
permanent and temporary streams manage to refill the area during wet season and a high level of vegetation coverage absorbs and maintains water levels. Thus, Burabay lake did not register a decline in water. The relative stability over the last 10 years shows that the ecological system created by the mountain range will most probably prevent both lakes from losing critical quantities of water during the next 10 years, if further development of tourism and other water-consuming activities is under constant monitoring. This can be supported by the research of Wu et al. (2014), where the water quality and quantity of mountain lakes in Xinjiang region in China slightly fluctuated and have not significantly changed over the past decade. The lake area has been stable and relatively insensitive to climate change. However, continuous growth of accommodation infrastructure and consequently of water consumption may influence the lacustrine area.

\section{- Ulken Shabakty and Kishy Shabakty lakes}

area is situated in a different geographical context. Tourism activities and human settlements are dominant in the eastern side, near the Ulken Shabakty lake. Steppe vegetation dominates the surroundings. To the west, the presence of activities around Kishy Shabakty lake is only incipient, without specific infrastructures. The surrounding land is dominated by agriculture, a massive consumer of lacustrine water. Thus, the reduction of the surface is due to growing activities near Akylbay town ( 1000 people). In the same time, considering that tourism infrastructure is planned to increase along the Lakes Ulken Shabakty and Kishi Shabakty, it might result in a quicker drop of the water surface area in the future.

\section{Conclusions}

The present study examined the possible effects of tourism development in ShchuchinskBurabay resort area upon the surface area of its four main lakes. By analysing the changes in water surface area over the years, tourism has been retained as one of the influencing elements, as changes in lake area reflect the combined effects of climate change, water inflow, industry, household and other anthropogenic activities.
The results indicate that the main surface water resources of the studied area have been facing environmental challenges during the last 30 years. The lakes have been losing water in that time, with variations depending on geographical location and water consumption pattern of human activities. According to previous studies, climate change influences the lake environment, however the direct human activities, characterised by high water demand and consumption, exert a greater role.

A number of papers have examined the effects of tourist activities on coastal, marine, lakeshore areas, mostly revealing negative consequences arising from tourism. So far, most studies have focused on direct impacts of tourism on water bodies, whereas this research provides a number of important insights, especially with regards to indirect effects of tourism activity on the lake area, by devoting a high attention to the accommodation sector. In particular, we have attempted to understand how water consumption by various type of accommodation influences the lakes' surface area. After a thorough assessment of tourism accommodation impact on the surface of the examined lakes, the results indicate that the loss of $11 \%$ in water area of Shortandy Lake and $15 \%$ of Ulken Shabakty Lake is partly explained by the nearby high concentration of accommodation businesses. Moreover, each type of accommodation has a specific influence on the amount of water consumption, where sanatoriums are the highest water consumers.

However, the overcrowded places and the great number of accommodation establishments around Burabay Lake did not induce a high water loss. This is explained by the presence of smaller establishments, which have a typical low-consumer behaviour, with small impact on the lake resources. The bigger size and variety of activities/services offered by accommodation businesses near Shortandy Lake correspond to higher water consumption by facilities and important water loss.

The quantitative overview of total direct water consumption within the accommodation establishments combined with local population accounts for $0.8 \%$ of total water volume of examined lakes per year. Further calculus of 
indirect water consumption may reveal in the future more impact of these activities.

Hence, as most tourism water consumption is related to the accommodation facilities, the future water management policies should target this sector first. The accommodation industry could contribute to improving water quality by building sewage treatment systems and mitigate the environmental issues associated with the exploitation of the lake water resources by introducing water saving measures. Furthermore, these measures need to be implemented by involving and empowering local people in the decision-making processes, which could contribute to a sustainable tourism development.

Thus, in destinations such as the ShchuchinskBurabay resort area, with a sensitive lake ecosystem, prevention of pollution and protection of the natural water resources should become essential.

In future water management plans, special regard needs to be given to the planned activities and possible direct and indirect impacts of tourism, according to the specifics of each lake. The Great Lakes in USA and Canada, or the Lake District in the UK, could be a good example of developing such plans for each lake based on the integrated lakes management approach.

Overall, in order to examine the influence of the tourism industry on the lacustrine environment, future research may reach a complex calculus of water balance by taking into account a wide range of important environmental and socioeconomic factors from land use, agriculture, industry and population dynamics. Thus, future expansion of research on tourismwater nexus should be encouraged and scientific results must be taken into consideration when developing future lake water management plans.

\section{Acknowledgements}

This work was supported by Coimbra Group Scholarship Programme for Young Researchers from European Neighbouring Countries and the grant has been awarded by Alexandru Ioan Cuza University of Iași,
Romania. Thanks are given to C. Beans for the English language revision.

\section{References}

Alifujiang, Y., Abuduwaili, J., Ma, L., Samat, A., \& Groll, M. (2017). System Dynamics Modeling of Water Level Variations of Lake Issyk-Kul, Kyrgyzstan. Water, 9(12), 989.

Angel, J.R., \& Kunkel, K.E. (2010). The response of Great Lakes water levels to future climate scenarios with an emphasis on Lake Michigan-Huron. Journal of Great Lakes Research, 36(2), 51-58.

Bhateria, R., \& Jain, D. (2016). Water quality assessment of lake water: a review. Sustainable Water Resources Management, 2(2), 161-173.

Bohdanowicz, P., \& Martinac, I. (2007). Determinants and benchmarking of resource consumption in hotels-Case study of Hilton International and Scandic in Europe. Energy and buildings, 39(1), 82-95.

Bucak, T., Trolle, D., Andersen, H.E., Thodsen, H., Erdoğan, Ş., Levi, E.E., Filiz, N., Jeppesen, E., \& Beklioğlu, M. (2017). Future water availability in the largest freshwater Mediterranean lake is at great risk as evidenced from simulations with the SWAT model. Science of the Total Environment, 581, 413-425.

Budnikova, T., Musataeva, G., \& Plokhih, R. (2010). Report on Integrated Ecological Studies of the Shchuchinsk- Burabay Resort Area for the Definition of the Ways of Sustainable Development (In Russian). Astana: The Institute of Geography.

Burak, S.A., Dogan, E., \& Gazioglu, C. (2004). Impact of urbanization and tourism on coastal environment. Ocean \& Coastal Management, 47(9-10), 515-527.

Cai Y, Sun G, Guo Z, Liu L, \&Yang L (2009). Simulation for influence of climate change on the stream flow variation in Poyang Lake basin. Resource Sciences 31(5), 743-749.

Charara, N., Cashman, A., Bonnell, R., \& Gehr, R. (2011). Water use efficiency in the hotel sector of Barbados. Journal of Sustainable Tourism, 19(2), 231-245.

Committee on Statistics of the Ministry of national economy. (2017). The official statistical information. Republic of Kazakhstan. URL: http://stat.gov.kz/faces/homePage?_afrLoop $=613307267 \quad 4571472 \# \% 40 \% 3 \mathrm{~F}$ _afrLoop $\%$ 3D6133072674571472\%26 adf.ctrl-state\%3 Dpsukn3e1r_17 (Accessed on 14.12.2017). 
Connor, R. (2015). The United Nations world water development report 2015: water for a sustainable world (Vol. 1). UNESCO Publishing.

Cooper, C. (2006). Lakes as tourism destination resources. Lake Tourism. An integrated approach to lacustrine tourism systems, 27-42.

Department of Statistics in Akmola region, Committee on Statistics of the Ministry of national economy. 2017. Tourism statistics. Republic of Kazakhstan. URL: www.oblstat.online.kz (Accessed on 14.12.2017).

Department of Tourism in Akmola region. (2017). Tourism information. URL: www.turism. kdt.kz (Accessed on 28.12.2017).

Dibike, Y.B., \& Coulibaly, P. (2005). Hydrologic impact of climate change in the Saguenay watershed: comparison of downscaling methods and hydrologic models. Journal of hydrology, 307(1-4), 145-163.

Dokulil, M.T. (2014). Environmental impacts of tourism on lakes. Eutrophication: causes, consequences and control, Springer Netherlands, 81-88.

Essex, S., Kent, M., \& Newnham, R. (2004). Tourism development in Mallorca: is water supply a constraint? Journal of Sustainable Tourism, 12(1), 4-28.

EUROSTAT. (2009). Water and Tourism Pilot Study. Luxemburg: Office for Official Publications of the European Communities.

Foghagen, C. (2014). The blooming paradise: algae blooms, environmental change and tourism. European Journal of Tourism Research, 7, 79.

Fong, S.F., \& Lo, M.C. (2015). Community involvement and sustainable rural tourism development: Perspectives from the local communities. European Journal of Tourism Research, 11, 125-146.

Gladstone, W., Curley, B., \& Shokri, M.R. (2012). Environmental impacts of tourism in the Gulf and the Red Sea. Marine pollution bulletin, 72(2), 375-388.

Gössling, S. (2001). The consequences of tourism for sustainable water use on a tropical island: Zanzibar, Tanzania. Journal of environmental management, 61(2), 179191.

Gössling, S., Peeters, P., Hall, C.M., Ceron, J.P., Dubois, G., \& Scott, D. (2012). Tourism and water use: Supply, demand, and security. An international review. Tourism Management, 33(1), 1-15.
Gössling, S., Hall, C.M., \& Scott, D. (2015). Tourism and water. Channel View Publications.

Hadjikakou, M., Chenoweth, J., \& Miller, G. (2013). Estimating the direct and indirect water use of tourism in the eastern Mediterranean. Journal of environmental management, 114,548-556.

Hadwen, W.L., Arthington, A.H., \& Mosisch, T.D. (2003). The impact of tourism on dune lakes on Fraser Island, Australia. Lakes \& Reservoirs: Research \& Management, 8(1), 15-26.

Hall, C.M., \& Härkönen, T. (2006). Lake tourism: An integrated approach to lacustrine tourism systems. Channel view publications.

Hamele, H., \& Eckardt, S. (2006). Environmental initiatives by European tourism businesses. Instruments, indicators and practical examples. A contribution to the development of sustainable tourism in Europe. Ecotrans and University of Stuttgart, Life Environmental Programme of the European Commission.

Jalili, S., Hamidi, S.A., \& Namdar Ghanbari, R. (2016). Climate variability and anthropogenic effects on Lake Urmia water level fluctuations, northwestern Iran. Hydrological sciences journal, 61(10), 1759-1769.

Kasim, A., Gursoy, D., Okumus, F., \& Wong, A. (2014). The importance of water management in hotels: a framework for sustainability through innovation. Journal of Sustainable Tourism, 22(7), 1090-1107.

Kazhydromet of the Ministry of Energy of the Republic of Kazakhstan. (2017). Environmental monitoring bulletin. URL: https:// kazhydromet.kz/ (Accessed on 10.12.2017).

Kumar, A., Sharma, M.P., \& Yadav, N.S. (2014). Assessment of Water Quality Changes at Two Locations of Chambal River: MP. J. Mater. Environ. Sci, 5, 1781-1785.

Kurleto, M. (2013). Sustainable management of lakes taking into consideration the tourism and nature conservation in Australia and New Zeland. PUBLISHER UWM, 91.

Lake, P.S., \& Bond, N.R. (2007). Australian futures: freshwater ecosystems and human water usage. Futures, 39(2-3), 288-305.

Lange, G.M. (2015). Tourism in Zanzibar: Incentives for sustainable management of the coastal environment. Ecosystem Services, 11, 5-11.

Lin, M., Xiao, X., Xu, Y., \& Xie, H. (2013). The impact of water quality changes on tourism capacity at Golden Lake. China Journal of 
Effects of tourism development on surface area of main lakes of Shchuchinsk-Burabay resort area, Kazakhstan.

Food, Agriculture and Environment, 11, 1069-1072.

Ministry of Agriculture of the Republic of Kazakhstan. (2017). Report. URL: http:// mgov.kz/en/ (Accessed on 12.12.2017).

Mooij, W.M., Hülsmann, S., Domis, L.N.D.S., Nolet, B.A., Bodelier, P.L., Boers, P.C., Pires, L.M.D., Gons, H.J., Ibelings, B.W., Noordhuis, R., \& Portielje, R. (2005). The impact of climate change on lakes in the Netherlands: a review. Aquatic Ecology, 39(4), 381-400.

National Laboratory of Astana. (2016). Report on research and development in the field of energy efficiency and conservation, renewable energy and environmental protection for 2014-2016. Astana. Kazakhstan.

Ning, B., \& He, Y. (2007). Tourism development and water pollution: case study in Lijiang Ancient Town. China Population, Resources and Environment, 17(5), 123-127.

Ostendorp, W., Schmieder, K., \& Jöhnk, K.D. (2004). Assessment of human pressures and their hydromorphological impacts on lakeshores in Europe. International Journal of Ecohydrology \&Hydrobiology,4(4),379-95.

Pyatov, E. (2007). Role of Shchuchinsk-Burabay resort area in tourism development. International Scientific Practice Conference on Tourism, Environment and Business, $23^{\text {rd }}$ $-25^{\text {th }}$ May 2007, Kokshetau, Kazakhstan.

Ramazanova, M.A., Tortella, B.D., Tirado, D., \& Kakabayev,A.A. (2016). Water and Tourism in Kazakhstan: Present and Future. Paper presented at the 6th International Conference on Tourism and Hospitality between China and Spain (ICTCHS 2016) with special extension to Latin America, $27^{\text {th }}-30^{\text {th }}$ September 2016, Madrid.

Rico-Amoros, A.M., Olcina-Cantos, J., \& Saurí, D. (2009). Tourist land use patterns and water demand: Evidence from the Western Mediterranean. Land Use Policy, 26(2), 493501.

Rodrigues, A.I., Correia, A., Kozak, M., \& Tuohino, A. (2015). Lake-destination image attributes: content analysis of text and pictures. Marketing Places and Spaces, 293-314.

Romanescu, G., losub, M., Sandu, I., Minea, I., Enea, A., Dascalita, D., \& Hapciuc, O.E. (2016). Spatio-temporal Analysis of the Water Quality of the Ozana River. Revista de Chimie (Bucharest), 67(1), 42-47.

Romanova, S.M., \& Kazangapova, N.B. (2013). Quality of waters lakes Kazakhstan in contemporaneous period (for example of Lake Kopa). International Journal of Biology and Chemistry, 6(2), 65-70.

Sevkaznedra, Interregional Department. (2014). Results of hydrogeological work upon the object Compilation of modern hydrogeological map of the ShchuchinskBurabay resort area in Akmola region. Kostanay, Kazakhstan: Report.

Sulnu, U. (2003). Environmental impacts of tourism. In Camarda D. (ed.), Grassini L. (ed.). Local resources and global trades: Environments and agriculture in the Mediterranean region. Bari: CIHEAM, Options Mediterraneans: Series A. Seminars Mediterraneans, 57, 263-270.

Tortella, B.D., \& Tirado, D. (2011). Hotel water consumption at a seasonal mass tourist destination. The case of the island of Mallorca. Journal of Environmental Management, 92(10), 2568-2579.

Volchak, A., Choiński, A., Kirviel, I., \& Parfomuk, S. (2017). Spectral analysis of water level fluctuations in Belarusian and Polish lakes. Bulletin of Geography. Physical Geography Series, 12(1), 51-58.

Water Resources Committee of the Ministry of Agriculture of the Republic of Kazakhstan. (2016). Report on household water consumption. URL: http://mgov.kz/en/ komitet-po-vodnym-resursam-msh-rk/ (Accessed on 10.11.2016).

World Tourism Organization. (2013). Tourism and Water. World Tourism Day. Madrid: UNWTO.

Wu, J., Liu, W., Zeng, H., Ma, L., \& Bai, R., (2014). Water quantity and quality of six lakes in the arid Xinjiang region, NW China. Environmental Processes, 1(2), 115125.

Yapiyev, V., Sagintayev, Z., Verhoef, A., Kassymbekova, A., Baigaliyeva, M., Zhumabayev, D., Malgazhdar, D., Abudanash, D., Ongdas, N., \& Jumassultanova, S. (2017). The changing water cycle: Burabay National Nature Park, Northern Kazakhstan. Wiley Interdisciplinary Reviews: Water, 4(5).

Yuan, Y., Zeng, G., Liang, J., Huang, L., Hua, S., Li, F., Zhu, Y., Wu, H., Liu, J., He, X., \& He, Y. (2015). Variation of water level in Dongting Lake over a 50-year period: Implications for the impacts of anthropogenic and climatic factors. Journal of Hydrology, 525, 450-456. 